\title{
Medicinal plants profile used by the 3rd District population of Maceió-AL
}

\author{
S. A. S. Griz ${ }^{a *}$, T. J. Matos-Rocha, ${ }^{a, b}$, A. F. Santos ${ }^{a, c}$, J. G. Costa ${ }^{d}$ and K. C. Mousinho ${ }^{a}$ \\ ${ }^{a}$ Centro Universitário Cesmac - CESMAC, Rua Cônego Machado, CEP 57051-160, Maceió, AL, Brazil

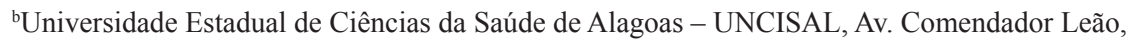 \\ CEP 57025-000, Maceió, AL, Brazil \\ 'Universidade Estadual de Alagoas - UNEAL, Rua Governador Luiz Cavalcante, s/n, Alto Cruzeiro, \\ CEP 57300-005, Arapiraca, AL, Brazil \\ 'Empresa Brasileira de Pesquisa Agropecuária - EMBRAPA, Tabuleiro Costeiro, CEP 57580-000, Maceió, AL, Brazil \\ *e-mail: samaraagriz@yahoo.com.br
}

Received: January 19, 2016 - Accepted: June 29, 2016 - Distributed: November 31, 2017

\begin{abstract}
Herein the use of medicinal plants by the population of the 3rd Sanitary District of Maceió-AL city is reported. Transversal description was conducted from February 2013 to January 2014, with a sample of 116 individuals of both Gender Genders aged over 18 years. The ethnobotanical information interviews ethnobotanical information were obtained through semi - structured questionnaire featuring the use of medicinal plants and social and economical data. Descriptive statistics was applied for quantitative variables as mean and standard deviation and proportions for qualitative variables in the frequency table format. The results showed that $85.34 \%$ of the interviewees used plants for medicinal purposes. As the majority of these were (73.28\%) females in the age group between 30-60 years of old. Among a total of 45 identified plant species, the highest use frequency were for Boldus Peumus (bilberry), Melissa officinalis (lemon balm), and Mentha piperita (mint). The most widely used plant foliage part was (53.53\%) prepared as an infusion (55.5\%). The use of medicinal plants in Maceió cityis widespread, highlighting the importance of ethnobotanical knowledge for the study of medicinal plants.
\end{abstract}

Keywords: medicinal plants, ethnobotanical, herbal medicine.

\section{Perfil de plantas medicinais utilizadas pela população do $3^{\circ}$ Distrito Sanitário de Maceió-AL}

\section{Resumo}

O presente estudo teve como objetivo analisar o perfil de utilização de plantas medicinais dos indivíduos residentes no $3^{\circ}$ Distrito Sanitário do município de Maceió, Alagoas. Trata-se de um estudo observacional, descritivo de caráter transversal que foi realizado no período de fevereiro de 2013 a janeiro de 2014, com amostra de 116 indivíduos, maiores de 18 anos de ambos os gêneros. As informações etnobotânicas foram obtidas através de entrevistas semi-estruturadas realizadas por meio de questionário semiestruturado para traçar o perfil de utilização de plantas medicinais e dados socioeconômicos e demográficos dos entrevistados. A estatística descritiva foi aplicada para as variáveis quantitativas na forma de média e desvio padrão e proporções para variáveis qualitativas no formato de tabelas de frequência. Os resultados evidenciaram que $85,34 \%$ dos entrevistados utilizavam plantas para finalidades medicinais. Sendo a maioria destes, (73,28\%) do Gênero feminino estando na faixa etária de 30 a 60 anos de idade. De um total de 45 espécies vegetais identificadas, as de maior frequência de utilização foram o Peumus boldus (boldo), a Melissa officinalis (erva-cidreira) e a Menta piperita (hortelã). A parte mais utilizada das plantas foi às folhas (53,53\%) sendo ainda esta preparada sob forma de infusão (55,5\%). A utilização de plantas medicinais no município de Maceió, Alagoas é bastante difundida, reforçando a importância de estudos etnobotânicos a fim de trabalhar com o resgate do conhecimento popular aliado a literatura científica.

Palavras-chave: plantas medicinais, etnobotância, fitoterapia.

\section{Introduction}

The use of medicinal plants for the diseases relief is a very ancient and widespread practice in humanity and in recent decades has had a significant increase by the emergence of the natural concept (Pedroso-Júnior and Sato, 2005). This is due to the cat that the interpretation of this concept represents for a share of the population, 
the absence of chemicals, which would be those that can cause some damage or otherwise represent danger to people's health (Vieira et al., 2010; Santana et al., 2016).

The appreciation of traditional therapies has been strengthened by the propositions of WHO, once that they are being considered as therapeutic options used to a large extent to meet the demands of population health and useful programs for primary health care, allowing autonomy in the users' health care of the public health system envisaged in the concept of health promotion (OMS, 2012).

Considering the increasing spread of the medicinal plants use, and this especially relates to the low cost and ease of access by the population, the national and international markets in the area of herbal medicines and these won expansion. Many studies have evaluated the biological extracts activity or metabolites due to the great use of medicinal plants by the population (Martins et al., 2016; Camargo et al., 2016).

There are few studies in the literature on social representations in alternative and complementary practices in Brazilian cities, since the focus of the research backs to the rural area. In this way, it is important to survey those characteristics, since this information may be useful in the public health policies implementation, as well as in the development of health attention programs that benefit the service's users (Marques et al., 2011).

In addition, epidemiological studies on the use of medicinal plants are relevant in order to promote the rational use of the same and be able to contribute with healthcare professionals so that they work in parallel with the superstitions from cultural plurality and users perceptions through appropriate guidance on the use of medicinal plants. Thus, the objective of this study was to analyze the profile of use of medicinal plants in the 3rd Health District in Maceió city, Alagoas.

\section{Material and Methods}

This was an observational study, descriptive with cross character that was conducted during the period from February 2013 to January 2014 with individuals who agreed to participate in the interview, equal to or over eighteen years of age, of both Genders, living in the 3rd Health District of Maceió city-AL and who signed the Free and clear Clarification Term-FICS. Individuals with any apparent cognitive disability, residing in churches, schools and points of sale were excluded.

The research was approved by the Research Ethics Committee of the Centro Universitário Cesmac under number 167.112.

Maceió city-AL, in 2010, was divided into eight health districts, corresponding to the eight administrative regions of the municipality, law No. 5486 2005. The 3rd District population of Maceió-AL, includes 8 (eight) districts: Jardim Petrópolis, Canaan, Ouro Preto, Santo Amaro, Gruta de Lourdes, Patel, Pitanguinha, Farol, which are habited with a total of 81994 people (IBGE, 2011).
Sample calculations were performed through the EPI-INFO ${ }^{\circledR}$ software version 3.3.2, considering the expected frequency of 85 for the use of medicinal plants, assuming a maximum 5 estimation error and the confidence level of 95. It has been estimated the minimum size of the sample in 96 individuals and 20 has been added to compensate for possible losses and refusals, totaling a minimum sample of 116 respondents.

Random drawing was held initially, among the eight randomized sanitary districts, being the 3rd district awarded for the research.

Sequentially, trying to reproduce the behavior in the population under study, the eight neighborhoods were described that are part of the $3 \mathrm{rd}$ district. Seeking to analyze the different socioeconomic strata, each one of them received a numerical and alphabetical sequence to its identification and subsequent visits.

Held by the conglomerate searching followed:

1. In each of the eight districts, Census sectors were identified, which were selected through a random drawing and proportional for the total users of the age group targeted by each of these sectors, taking also into account the sample calculation, so that there was an even distribution of the sample. Some sectors were excluded from census: churches, schools and shopping.

2. The selection of the streets to visit took place through random sampling by conglomerates, being the streets identified by serial numbers and then drawn using the Microsoft Excel version XP ${ }^{\circledR}$.

3. The households were selected randomly in a clockwise direction. The interviews were conducted in the number of households in each sector. The interviewer should move to the next domicile available, just in case there is nobody in at the time of the visit, or that in case the residents did not comply with the study inclusion criteria. This procedure should be followed to the next domicile, until the identification of an individual or more who were residing in the same domicile and they were eligible (Tomazzoni, 2004).

4. The interviewer should still transpose to the adjacent sequenced neighborhood at the time when he or she had already passed through an entire census and if he or she had not got the contemplation of the total number of interviews planned for that specific neighborhood. Facing the occurrence of more than one eligible individual at home, all of them were interviewed.

In order to obtain the information related to socio-economic and demographic variables (independent), described in the data collection form, and ethnobotanical (dependent), in questionnaire which includes structured and semi-structured questions, semi structured interviews were carried out individually under the supervision of the responsible researcher, in the volunteers' households. 
The socioeconomic and demographic data form was composed by the variables: name, address, gender, age, education, occupation, household income, type of housing, basic sanitation, number of residents and medical care.

To analyze the profile of use of medicinal plants, with respect to the Ethnobotanical aspects, the data collection instrument applied was a semi-structured questionnaire based on the methodologies Rodrigues and Carvalho (2001) and Marchese et al. (2009). The variables analyzed were: medicinal plants used, obtaining of the plants, use mode, purpose, obtaining of this knowledge and species used.

A pilot study was conducted with 24 (twenty four) appicants who corresponded to about $20 \%$ out of the total sample, in order to identify the possible questions of the respondents concerning the form questions and Ethnobotanical survey, and thus to carry out the necessary modifications.

Educational workshop was held for the respondents of the study that accepted the invitation in February 2014, where relevant issues were discussed about the importance of medicinal plants in the context of the health system, indications, medicinal plants preparation and packaging most mentioned by the study population. During the meeting, folders containing educational information were handed discussed and recommended by the scientific literature.

For reading and tab of the results obtained, it was built a database in Microsoft Excel ${ }^{\circledR}$ 2010. Statistical analysis was performed using the BioEstat ${ }^{\circledR}$ program version 5.0.
The descriptive statistics was applied for the quantitative variables in the form of mean values and standard deviation, whereas a confidence interval of 95 and proportions for qualitative variables in the form of frequency tables.

The Shapiro-Wilk and Lilliefors were used to determine the data normality. To determine differences between the different classes within the socioeconomic variables and use of medicinal plants inferential statistics was used through the $\chi^{2}$ test. Spearman correlation estimates were used to determine the relationship between variables and the popular use of medicinal plants. In all the analyses, the value of $\mathrm{p} \leq 0.05$ was considered as significant. The programs used were GENES and Assistat-normality and descriptive statistics.

\section{Results}

The results of this study show that the 116 participants, $85.34 \%$ stated to make use of medicinal plants for therapeutic purposes.

On sample characterization with respect to socioeconomic variables, it was observed that most were female (73.28\%), married (55.17\%), with a job (62.94\%), education level higher (40.51) and family income greater than five minimum wages (16.38) (Table 1).

Considering the frequency use of medicinal plants, it was observed that there was only significant difference regarding family income $(\mathrm{p} \leq 0.05)$, which featured $100 \%$ of the respondents' usage frequency for the category

Table 1. Often observed for the different classes of socioeconomic variables among users of medicinal plants.

\begin{tabular}{|c|c|c|c|c|c|}
\hline & \multicolumn{2}{|c|}{ VARIABLE } & NUMBER & $\begin{array}{c}\text { FREQUENCY } \\
\text { OF USE (\%) }\end{array}$ & $P *$ \\
\hline \multicolumn{6}{|l|}{ Gender } \\
\hline & 1. & Male & 31 & 87.10 & \multirow{2}{*}{0.87} \\
\hline & 2. & Female & 85 & 84.71 & \\
\hline \multicolumn{6}{|c|}{ Marital status } \\
\hline & 1. & Single (a) & 52 & 71.15 & \multirow{2}{*}{0.12} \\
\hline & 2. & Married (a) & 64 & 96.87 & \\
\hline \multicolumn{6}{|c|}{ Occupation } \\
\hline & 1. & Housewife & 20 & 90.00 & \multirow{5}{*}{0.89} \\
\hline & 2. & Retired (a) & 10 & 80.00 & \\
\hline & 3. & Employee (a) & 73 & 84.93 & \\
\hline & 4. & Estudante & 13 & 84.61 & \\
\hline & 5. & Student (a) & - & - & \\
\hline \multicolumn{6}{|c|}{ Education degree } \\
\hline & 1. & Illiterate & 8 & 100 & \multirow{4}{*}{0.55} \\
\hline & 2. & Elementary School & 16 & 87.50 & \\
\hline & 3. & High school & 45 & 84.44 & \\
\hline & 4. & Upper level & 47 & 82.98 & \\
\hline \multicolumn{6}{|c|}{ Family Income } \\
\hline & 1. & $<1$ minimum wage & 6 & 66.67 & \multirow{4}{*}{$0.03 *$} \\
\hline & 2. & From 1 to 3 salaries & 45 & 73.33 & \\
\hline & 3. & $>3$ to 5 salaries & 46 & 93.48 & \\
\hline & 4. & $>5$ salaries & 19 & 100.00 & \\
\hline
\end{tabular}

*Significant by the chi-square test $(\mathrm{p}<0.05)$. 
greater than five minimum wages, evidencing high income economy. It was determined that there is strong and positive correlation between this variable and use of medicinal plants with correlation coefficient or 0.79 (Table 1).

With respect to the characterization of the sample with regard to socio-demographic variables, it was observed that most of them reside in houses $(53.45 \%)$ own $(87.07 \%)$ and sanitation $(56.90 \%)$. In most houses were resided by three or four residents $(83.87 \%)$, whose access to health care was done primarily through private health plan (75.86\%) (Table 2).

The comparative analysis of these variables with the use of medicinal plants showed that there was no significant difference between the observed frequencies $(\mathrm{p} \leq 0.05)$ (Table 2).
Considering the sample characteristics concerning the ethnobotanical variables, it was observed that most of the knowledge about the medicinal plants came about through the family $(83.33 \%)$, being indicated for medicinal purposes by friends and relatives $(56.03 \%)$. It is realized that $56.04 \%$ of the users consider sufficient the diseases treatment with medicinal plants (Table 3).

In relation to the access to the plants, $39.65 \%$ reported to have obtained them in free fairs. On completion of treatment with continuous-use medication, $68.10 \%$ use them and $67.24 \%$ stated not to have the habit of using parallel to allopathic medicinal plants treatment. Regarding dosage $53.45 \%$ uses what is recommended by family and friends, as well as the majority $52.59 \%$ does not store the plants before preparing them.

Table 2. Often observed for the different classes of demographic variables among users of medicinal plants.

\begin{tabular}{|c|c|c|c|c|}
\hline \multicolumn{2}{|c|}{ VARIABLE } & \multirow[t]{2}{*}{ NUMBER } & \multirow[t]{2}{*}{$\begin{array}{c}\text { FREQUENCY } \\
\text { OF USE (\%) } \\
\end{array}$} & \multirow[t]{2}{*}{$P^{*}$} \\
\hline \multicolumn{2}{|c|}{ Kind of Residence } & & & \\
\hline 1 & House & 62 & 83.87 & \multirow{2}{*}{0.81} \\
\hline 2 & Apartment & 54 & 87.04 & \\
\hline \multicolumn{5}{|l|}{ Residence } \\
\hline 1 & Own & 101 & 87.13 & \multirow{3}{*}{0.48} \\
\hline 2 & Rented & 13 & 84.61 & \\
\hline 3 & Others & 2 & 100.00 & \\
\hline \multicolumn{5}{|l|}{ Sanitation } \\
\hline 1. & Sewerage & 66 & 83.33 & \multirow{2}{*}{0.70} \\
\hline 2. & Cesspit & 50 & 88.00 & \\
\hline \multicolumn{5}{|c|}{ number of residents } \\
\hline 1. & $<2$ & 29 & 93.10 & \multirow{3}{*}{0.65} \\
\hline 2. & From 2 to 4 & 69 & 81.16 & \\
\hline 3. & $>4$ & 18 & 88.89 & \\
\hline \multicolumn{5}{|l|}{ Medical care } \\
\hline 1. & SUS - Ensurance public & 28 & 92.86 & \multirow{2}{*}{0.54} \\
\hline 2. & Ensurance - Private & 88 & 85.23 & \\
\hline
\end{tabular}

*Significant by the chi-square test $(\mathrm{p}<0.05)$.

Table 3. Often observed for the different classes of ethnobotanical variables ethnobotanical among users of medicinal plants.

\begin{tabular}{|c|c|c|c|c|}
\hline & ARIABLE & AMOUNT & $\begin{array}{c}\text { FREQUENCY } \\
\text { OF USE }(\%)\end{array}$ & $P^{*}$ \\
\hline \multicolumn{5}{|l|}{ Knowledge } \\
\hline 1 & Family & 96 & 83.33 & \multirow{4}{*}{$0.03 *$} \\
\hline 2 & Friends & 10 & 60.00 & \\
\hline 3 & Professional Health & 6 & 66.67 & \\
\hline 4 & Courses in the area & 4 & 50.00 & \\
\hline \multicolumn{5}{|l|}{ Indication } \\
\hline 1 & Health professional & 38 & 89.47 & \multirow{3}{*}{0.36} \\
\hline 2 & Friends and relatives & 65 & 81.25 & \\
\hline 3 & Used it once and it worked & 13 & 100.00 & \\
\hline \multicolumn{5}{|c|}{ Consider treatment with medicinal plants enough } \\
\hline 1 & Yes & $65(56.04)$ & $65(100)$ & \multirow{2}{*}{0.09} \\
\hline 2 & No & $51(43.96)$ & $40(78.43)$ & \\
\hline
\end{tabular}

*Significant by the chi-square qui-quadrado test $(\mathrm{p}<0.05)$. 
The comparative analysis of these variables with the use of medicinal plants indicated a significant difference only with respect to the knowledge $(\mathrm{p} \leq 0.05)$ (Table 3$)$.

45 species of plants were mentioned by the participants of the study, Plectranthus barbatus, Lippia alba and Menta piperita were the three most mentioned (Table 4). The most quoted was therapeutic indication for diseases of the gastrointestinal tract $(66.66 \%)$, with the leaves as part of the plant used (53.53\%). A total of $65.65 \%$ uses the oral route as the administration main route. Concerning the preparation mode most of the citations $(55.55 \%)$, refers to the infusion.

Out of the species mentioned, $88.89 \%$ had their popular use coinciding with the reported in the literature. Only the species Eugenia uniflora and Punica granatum showed an indication of use that is not in the literature consulted. In the same way that only the species Rosmarinus officinalis, Sambucus nigra and Punica granatum had the form of use or part used the divergent recommended by specialized literature (Table 4).

Table 4. Distribution of species of medicinal plants used by the concerned population.

\begin{tabular}{|c|c|c|c|c|c|}
\hline $\begin{array}{l}\text { Specie-scientific } \\
\text { name }\end{array}$ & Population's indication & Part used & $\begin{array}{l}\text { How to use } \\
\text { FORM }\end{array}$ & $\begin{array}{l}\text { Preparation } \\
\text { method }\end{array}$ & $\begin{array}{c}\text { Species } \\
\text { quoting } \\
\text { Frequency } \\
(\%)\end{array}$ \\
\hline $\begin{array}{l}\text { Cynara } \\
\text { scolymus }\end{array}$ & Fat reducer & Leaf & Orally & infusion & 0.86 \\
\hline $\begin{array}{l}\text { Rosmarinus } \\
\text { officinalis }\end{array}$ & $\begin{array}{c}\text { Skin diseases } \\
\text { Fever } \\
\text { Pains } \\
\end{array}$ & $\begin{array}{c}\text { Leaf** } \\
\text { whole plant }\end{array}$ & $\begin{array}{c}\text { Orally } \\
\text { Topically } \\
\text { mouthwash }\end{array}$ & $\begin{array}{c}\text { Infusion } \\
\text { decoction syrup } \\
\text { macerated }\end{array}$ & 3.44 \\
\hline $\begin{array}{l}\text { Ocimum } \\
\text { champechianum }\end{array}$ & Respiratory system diseases & Leaf & Orally & decoction & 0.86 \\
\hline Allium sativum & $\begin{array}{l}\text { Respiratory system diseases } \\
\text { Soothing }\end{array}$ & $\begin{array}{c}\text { Bulb } \\
\text { whole plant }\end{array}$ & Orally & Infusion syrup & 2.59 \\
\hline Morus alba & $\begin{array}{c}\text { Hormonal } \\
\text { menstrual cramps }\end{array}$ & Leaf & Orally & infusion & 5.17 \\
\hline Carapa guianensis & Inflammation & Leaf & Orally & natural oil & 1.72 \\
\hline $\begin{array}{l}\text { Schinus } \\
\text { terebinthifolius }\end{array}$ & $\begin{array}{c}\text { Cicatrizant } \\
\text { utero inflammation }\end{array}$ & $\begin{array}{l}\text { Stem bark } \\
\text { leaf }\end{array}$ & $\begin{array}{l}\text { sitz bath } \\
\text { Orally }\end{array}$ & decoction & 2.59 \\
\hline Aloe vera & $\begin{array}{c}\text { Skin diseases } \\
\text { Cicatrizant }\end{array}$ & Stem & topically & $\begin{array}{c}\text { decoction } \\
\text { Cataplasm or } \\
\text { poultice }\end{array}$ & 5.17 \\
\hline $\begin{array}{l}\text { Abarema } \\
\text { cochliacarpos }\end{array}$ & $\begin{array}{l}\text { Skin diseases } \\
\text { Cicatrizant } \\
\text { Cancer } \\
\text { Pains } \\
\text { Inflammation }\end{array}$ & $\begin{array}{c}\text { leaf } \\
\text { stem } \\
\text { Stem bark }\end{array}$ & $\begin{array}{l}\text { Orally } \\
\text { topically } \\
\text { sitzbath }\end{array}$ & bottle & 4.31 \\
\hline $\begin{array}{l}\text { Plectranthus } \\
\text { barbatus }\end{array}$ & gastrointestinal diseases & Leaf & Orally & infusion & 35.54 \\
\hline $\begin{array}{l}\text { Specie-scientific } \\
\text { name }\end{array}$ & Population's indication & Part used & How to use & $\begin{array}{l}\text { Preparation } \\
\text { method }\end{array}$ & $\begin{array}{c}\text { Species } \\
\text { quoting } \\
\text { Frequency }\end{array}$ \\
\hline $\begin{array}{l}\text { Matricaria } \\
\text { recutita }\end{array}$ & Soothing & $\begin{array}{l}\text { Leaf flower } \\
\text { seed }\end{array}$ & Orally & infusion & 16.38 \\
\hline $\begin{array}{l}\text { Cinnamomum } \\
\text { zeylanicum }\end{array}$ & gastrointestinal diseases/pain & stem & Orally & infusion & 0.86 \\
\hline $\begin{array}{l}\text { Cymbopogon } \\
\text { citratus }\end{array}$ & $\begin{array}{l}\text { Gastrointestinal diseaeses/ } \\
\text { soothing/fever }\end{array}$ & Leaf & Orally & infusion/syrup & 12.07 \\
\hline $\begin{array}{l}\text { Baccharis } \\
\text { Trimera }\end{array}$ & Fat reducer & Leaf & Orally & infusion & 0.86 \\
\hline Equisetum ssp & - & Leaf & Orally & infusion & 1.72 \\
\hline Allium сера & Respiratory system diseases & whole plant & Orally & syrup & 1.72 \\
\hline
\end{tabular}

\footnotetext{
*Popular distinct indication of the scientific literature. *Part of the plant from popular use distinct from the scientific literature.
} 
Table 4. Continued...

\begin{tabular}{|c|c|c|c|c|c|}
\hline $\begin{array}{l}\text { Specie-scientific } \\
\text { name }\end{array}$ & Population's indication & Part used & How to use & $\begin{array}{l}\text { Preparation } \\
\text { method }\end{array}$ & $\begin{array}{c}\text { Species } \\
\text { quoting } \\
\text { Frequency }\end{array}$ \\
\hline $\begin{array}{l}\text { Camellia } \\
\text { sinensis }\end{array}$ & Fat reducer & Leaf & Orally & infusion & 2.59 \\
\hline Copaifera $s p$ & inflammation & Stem bark & Orally & natural oil & 1.72 \\
\hline $\begin{array}{l}\text { Lepidium } \\
\text { heterophyllum }\end{array}$ & Gastrointestinal diseases & fruit & Orally & infusion & 1.72 \\
\hline Lippia alba & $\begin{array}{c}\text { Respiratory diseases/ } \\
\text { gastrointestinal diseases/ } \\
\text { skin diseases/soothing/pain }\end{array}$ & $\begin{array}{l}\text { Leaf and } \\
\text { seed }\end{array}$ & Orally & $\begin{array}{c}\text { infusion/ } \\
\text { decoction/ } \\
\text { syrup macerated }\end{array}$ & 27.59 \\
\hline $\begin{array}{l}\text { Specie-scientific } \\
\text { name }\end{array}$ & Population's indication & Part used & How to use & $\begin{array}{l}\text { Preparation } \\
\text { method }\end{array}$ & $\begin{array}{c}\text { Species } \\
\text { quoting } \\
\text { Frequency }\end{array}$ \\
\hline Pimpinella anisum & $\begin{array}{l}\text { Gastrointestinal diseases/ } \\
\text { soothing/hormonal }\end{array}$ & $\begin{array}{c}\text { Leaf fruit } \\
\text { seed } \\
\text { whole plant }\end{array}$ & Orally & infusion & 8.62 \\
\hline $\begin{array}{l}\text { Eucalyptus } \\
\text { tereticornis }\end{array}$ & Respiratory diseases & Leaf & Orally & infusion & 1.72 \\
\hline Prunus dulcis & Pains & Leaf & Orally & infusion & 1.72 \\
\hline Citrus reticulata & Soothing & Leaf & Orally & $\begin{array}{l}\text { infusion/ } \\
\text { decoction }\end{array}$ & 0.86 \\
\hline $\begin{array}{l}\text { Zingiber } \\
\text { officinale }\end{array}$ & Pains and inflammation & Root & Orally & decoction & 1.72 \\
\hline Psidium guajava & Gastrointestinal diseases/pains & Leaf & Orally & decoction & 0.86 \\
\hline Anonna muricata & $\begin{array}{c}\text { Cardiovascular and } \\
\text { gastrointestinal diseases }\end{array}$ & Leaf & Orally & $\begin{array}{l}\text { Decoction } \\
\text { infusion }\end{array}$ & 0.86 \\
\hline $\begin{array}{l}\text { Abelmoschus } \\
\text { esculentus }\end{array}$ & Pains & Leaf & Orally & infusion & 1.72 \\
\hline Mentha piperita & $\begin{array}{c}\text { gastrointestinal and respiratory } \\
\text { diseases/ Fever/pains/ } \\
\text { menstrual cramps }\end{array}$ & Leaf & $\begin{array}{l}\text { Orally/ } \\
\text { inhaling }\end{array}$ & $\begin{array}{c}\text { infusion/ } \\
\text { decoction/ } \\
\text { syrup/ } \\
\text { macerated and } \\
\text { juice } \\
\end{array}$ & 18.96 \\
\hline $\begin{array}{l}\text { Specie-scientific } \\
\text { name }\end{array}$ & Population's indication & Part used & How to use & $\begin{array}{l}\text { Preparation } \\
\text { method }\end{array}$ & $\begin{array}{c}\text { Species } \\
\text { quoting } \\
\text { Frequency }\end{array}$ \\
\hline Cordia alliodora & Respiratory diseases & Leaf & Orally & infusion & 1.72 \\
\hline $\begin{array}{l}\text { Ocimum } \\
\text { Basilicum }\end{array}$ & Respiratory diseases & Leaf & Orally & infusion & 0.86 \\
\hline Passiflora edulis & $\begin{array}{c}\text { / } \\
\text { Respiratory and cardiovascular } \\
\text { diseases/soothing }\end{array}$ & Leaf fruit & Orally & $\begin{array}{l}\text { decoction/ } \\
\text { juice }\end{array}$ & 0.86 \\
\hline $\begin{array}{l}\text { Chenopodium } \\
\text { ambrosioides }\end{array}$ & worms & Leaf & Orally & juice & 1.72 \\
\hline $\begin{array}{l}\text { Mormodica } \\
\text { angolensis }\end{array}$ & hemorrhoids & Leaf & topically & $\begin{array}{l}\text { Decoction } \\
\text { macerated }\end{array}$ & 0.86 \\
\hline $\begin{array}{l}\text { Tarenaya } \\
\text { spinosa }\end{array}$ & $\begin{array}{c}\text { alergy/ } \\
\text { respiratory diseases }\end{array}$ & flower & Orally & $\begin{array}{l}\text { infusion/ } \\
\text { decoction }\end{array}$ & 0.86 \\
\hline Morinda citrifolia & $\begin{array}{c}\text { Respiratory diseases, cancer, } \\
\text { pains and arthritis }\end{array}$ & fruit & Orally & infusion & 1.72 \\
\hline $\begin{array}{l}\text { Annona } \\
\text { squamosa }\end{array}$ & $\begin{array}{c}\text { Respiratory and } \\
\text { gastrointestinal diseases }\end{array}$ & Leaf & Orally & infusion & 0.86 \\
\hline Eugenia uniflora & $*$ Cicatrizant & Leaf & Orally & decoction & 0.86 \\
\hline
\end{tabular}


Table 4. Continued...

\begin{tabular}{|c|c|c|c|c|c|}
\hline $\begin{array}{l}\text { Specie-scientific } \\
\text { name }\end{array}$ & Population's indication & Part used & How to use & $\begin{array}{l}\text { Preparation } \\
\text { method }\end{array}$ & $\begin{array}{c}\text { Species } \\
\text { quoting } \\
\text { Frequency }\end{array}$ \\
\hline $\begin{array}{l}\text { Phyllanthus } \\
\text { Niruri }\end{array}$ & menstrual cramps & Leaf & Orally & infusion & 1.72 \\
\hline Punica granatum & $\begin{array}{c}* \text { Respiratory diseases and } \\
\text { inflammation }\end{array}$ & Bark & Orally & decoction & 0.86 \\
\hline $\begin{array}{l}\text { Sambucus } \\
\text { Nigra }\end{array}$ & Fever/diuretic & $\begin{array}{l}* * \text { Leaf } \\
\text { flower }\end{array}$ & Orally & $\begin{array}{c}\text { infusion/ } \\
\text { decoction syrup }\end{array}$ & 0.86 \\
\hline Hyptispectinata & Skin diseases/cicatrizant & $\begin{array}{l}\text { Leaf Root } \\
\text { stem }\end{array}$ & $\begin{array}{l}\text { Topically } \\
\text { sitz bath }\end{array}$ & decoction & 5.17 \\
\hline $\begin{array}{l}\text { Cassia } \\
\text { angustifolia }\end{array}$ & laxative & Leaf & Orally & decoction & 1.72 \\
\hline $\begin{array}{l}\text { Uncaria } \\
\text { tomentosa }\end{array}$ & $\begin{array}{c}\text { Cicatrizant/ } \\
\text { anti-inflammatory }\end{array}$ & Stembark & Orally & decoction & 0.86 \\
\hline
\end{tabular}

*Popular distinct indication of the scientific literature. *Part of the plant from popular use distinct from the scientific literature.

\section{Discussion}

Considering the results found in this study, it was found that they corroborate with other described in the literature, since the population equivalent to $85.34 \%$ uses medicinal plants with therapeutic purpose. According to Edward et al., 2011 , it was observed that out of the 183 respondents, 71 stated to make use of medicinal plants and Silva et al. (2010), showed that from the population studied there was a $95.6 \%$ percentage of use of medicinal plants.

The data presented in this study consolidate what WHO reports, where $80 \%$ of the population of developing countries makes use of traditional medicine for their basic health needs, and about $85 \%$ of this, uses any plant, their plant extract, their active ingredients and/or their active principles at the medicines composition (Tomazzoni et al., 2006).

This trait can be explained due to the fact that the industrialized medicines high cost fosters the use of natural products and the use of medicinal plants has been appreciating in the urban environment, and it may no longer be a habit only from the countryside (Almassy Junior et al., 2005).

However, divergent results are also cited in the scientific literature, as in the study by Macedo et al. (2007), where $80.66 \%$ of respondents did not made use of medicinal plants, and Annichino et al. (1986), which featured only $10.8 \%$. These results can be explained considering that the life habits can be influenced by cultural relations that are transmitted over generations, and can be assigned to this aspect the convergences on the use of medicinal plants.

Regarding the influence of the variable gender in the use of plants, the results presented in this study differ from found by other researchers. In the study by Ethur et al. (2011), 54 of the users were women and $46 \%$ men, held by Ribeiro et al. (2005), 75\% were women. This behavior is prevalent also in studies conducted by Arnous et al. (2005) with 93\%, of women users of medicinal plants.
Another fact is the family income distributed over three to five minimum wages, which agrees with the findings of Macedo et al. (2007), pointing to increased use among individuals whose household income exceeded four minimum wages.

Different result was found by Arnous et al. (2005), in research carried out in the municipality of Datas-MG, where $85 \%$ of respondents that use plants in therapy are in the range from 0 to 3 minimum wages.

Considering this variable, it also checkes in the literature that the use of medicinal plants can be distributed proportionately across all income levels (Vendruscolo and Mentz, 2006).

Among respondents with regard to schooling, most of the respondents have college degree, according to the findings by Macedo et al. (2007), where 31\% of the respondents had the same schooling level, and it is possible to interpret that the users profile of medicinal plants is frequent in the middle of individuals with high level of enlightenment and economic conditions that favor the search and access to information.

The majority of the population that uses medicinal plants reported that they purchase them free fairs, unlike observed in other studies, where the plants are mostly grown in their homes (Pilla et al., 2006).

It is believed that the data can change depending on the characteristics of each municipality and they are linked to favouring culture and popular culture.

In this study it was also accomplished he influence of knowledge on medicinal plants for generations, as the majority of respondents claimed to have learned from family members. In the study by Albuquerque (1999) you can see also the knowledge of medicinal plants with their descendants. This fact is justified by culture, values and beliefs that are passed along generations. Being friends and relatives the most frequent contacts and that influenced the indication for the use of medicinal plants. 
Among the 45 plant species referred to in use by the participants of the study, peumus Boldus (bilberry), Melissa officinalis (lemon balm) Mint piperita (Mint) were the three most mentioned. This was confirmed in the study by Arnous et al. (2005) and Macedo et al. (2007), in which these three plants were among the twenty most referred to. A piece of information to be considered in this finding is related to these species to be common and adapt to the cultivation in several climates.

Among the 45 species mentioned, 10 is mentioned in the Collegiate Board resolution $\left(\mathrm{RDC}^{\circ} \mathrm{N}^{\circ} 10\right)$ of the National Agency of Sanitary Surveillance (ANVISA), which established a list of several medicinal plants of traditional use with scientifically proven effect, in addition to the correct forms of use and contraindications of the same (ANVISA, 2010).

20 plant species are listed at RENISUS considered as a potencial to forward at the productive chain stages and capable to generate products considered interesting to SUS (Brasil, 2011).

Most medical indications of this study are similar to those described in the scientific literature, corroborating with the described by Dôres et al. (2003). The use of medicinal plants arise mostly through popular knowledge reflected in the indiscriminate use, suggesting thus flaws in their therapy.

However, in this study, it was also noticed that medicinal plants have been used for purposes other than those listed in the literature, corroborating with the research by Costa et al. (1998), where you can see that some information in the scientific literature about the therapeutic indication of medicinal plants do not apply to some pathologies described by the popular use.

According to Tomazzoni (2004) notes that are not listed in the scientific literature may be either new and correct ways to use, as they can represent errors in the species identification, and can be linked to various popular names assigned. Differences were recorded between the use directions and preparation forms recommended by scientific literature.

The number of species mentioned, most were for the treatment of gastrointestinal tract, as also remarked by Oliveira and Menini Neto (2012). Already Mann et al. in 2004 showed that greater use was made of these plants for the influenza treatment accompanied by bronchitis.

The high use of leaves in the preparation of remedies was also detected in this study. Similar to the findings by Zucchi et al. (2013), both of them corroborating that the most referenced preparation method was also the infusion. According to Calixto and Ribeiro (2002), the species variation and of the goals that has the treatment to be held influence in the different choices on the part of the plant used and preparation. And this fact justifies the use of other parts and preparation of various forms. The findings in the study confirm as the treatment with medicinal plants being enough, similar result was found by Arnous et al. (2005).

\section{Conclusion}

This paper reveals the need for expansion of other studies involving the other actors that are inserted into the context of the health assistance of Maceió city-AL.

It is expected that the results presented could contribute to the proposed guidance on the rational use of medicinal plants as integrative health practice in partnership for the implementation of public policies aimed at this scope in Maceió city, in Alagoas State and in Brazil.

\section{References}

AGÊNCIA NACIONAL DE VIGILÂNCIA SANITÁRIA-ANVISA, 2010 [viewed 25 May 2012]. Resolução - RDC $n^{\circ}$ 10, de 9 de março de 2010. Dispõe sobre a notificação de drogas vegetais junto à Agência Nacional de Vigilância Sanitária (ANVISA) e dá outras providencias. Diário Oficial da República Federativa do Brasil [online], Brasília, 9 mar. Available from: http://bvsms.saude. gov.br/bvs/saudelegis/anvisa/2010/res0010_09_03_2010.html

ALBUQUERQUE, U.P., 1999. Manejo tradicional de plantas em regiões neotropicais. Acta Botanica Brasílica, vol. 13, pp. 307-315.

ALMASSY JÚNIOR, A. A.; LOPES, R. C.; ARMOND, C.; SILVA, F.; CASALI, V. W. D., 2005. Folhas de chá: plantas medicinais na terapêtica humana. Viçosa: Editora da Universidade Federal de Viçosa. 233 p.

ANNICHINO, G.P., IMAMURA, C.R.A., MAUAD, M.A., MEDEIROS, L.A., MORITA, I. and TOWATA, E.A., 1986. Medicina caseira em sete localidades da região de Bauru, SP. Cadernos de Saude Publica, vol. 2, no. 2, pp. 150-166. http:// dx.doi.org/10.1590/S0102-311X1986000200004.

ARNOUS, A.H., SANTOS, A.S. and BEINNER, R.P.C., 2005. Plantas medicinais de uso caseiro - conhecimento popular e interesse por cultivo comunitário. Revista Espaço para a Saúde, vol. 6, no. 2, pp. 1-6.

BRASIL, Ministério da Saúde, Secretaria de Ciência, Tecnologia e Insumos Estratégicos, Departamento de Assistência Farmacêutica e Insumos Estratégicos, 2011. Programa Nacional de Plantas Medicinais e Fitoterápicos. Brasília. 136 p. Série C. Projetos, Programas e Relatórios.

CALIXTO, J. S., RIBEIRO, E. M., 2002. O Cerrado como fonte de plantas medicinais para uso dos moradores de comunidades tradicionais do Alto Jequitinhonha, MG. Lavras: Universidade Federal de Lavras. Monograph.

CAMARGO, L., PEDROSO, L.S., VENDRAME, S.C., MAINARDES, R.M. and KHALIL, N.M., 2016. Antioxidant and antifungal activities of Camellia sinensis (L.) Kuntze leaves obtained by different forms of production. Brazilian Journal of Biology = Revista Brasileira de Biologia, vol. 76, no. 2, pp. 428434. PMid:26983085. http://dx.doi.org/10.1590/1519-6984.18814.

COSTA, A.F.E., FROTA, J.G., LIMA, M.C. and MORAES, M.O., 1998. Plantas medicinais utilizadas por pacientes atendidos nos ambulatórios do Hospital Universitário Walter Cantidio da Universidade Federal do Ceará. Pesq Med Fortaleza, vol. 1, no. 2, pp. 20-25.

DÔRES, R.G.R., PEREIRA, L.E., PEDROSA, C.D., SILVA, R.R., PINHEIRO, A.C.N., NASCIMENTO, C.B., SILVA, D.C.O., CAMPOS, G.B.W., BORGES, J., ALMEIDA, J.C.S., FREITAS, L.S., SILVA, L.C., FONTES, S.D., PEREIRA, T.M.C. 
and MIRANDA, T.M., 2003. Fitoterapia e alopatia: a atenção farmacêutica "verde". Infarma, vol. 15, no. 1/3, pp. 62-66.

ETHUR, L. Z.; JOBIM, J. C.; RITTER, J. G.; OLIVEIRA, G.; TRINDADE, B. S. Comércio formal e perfil de consumidores de plantas medicinais e fitoterápicos no município de Itaqui RS. Revista Brasileira de Plantas Medicinais, v. 13, n. 2, p. 121-128, 2011.

INSTITUTO BRASILEIRO DE GEOGRAFIA E ESTATÍSTICA - IBGE, 2011 [viewed 25 May 2012]. Cidades [online]. Available from: http://www.ibge.gov.br/cidades/painel.php?codmun=270430

MACEDO, A.F., OSHIIWA, M. and GUARIDO, C.F., 2007. Ocorrência do uso de plantas medicinais por moradores de um bairro do município de Marília - SP. Revista de Ciências Farmacêuticas Básica e Aplicada, vol. 28, no. 1, pp. 123-128.

MARCHESE, J.A., MING, L.C., FRANCESCHI, L., CAMOCHENA, R.C., GOMES, G.D., PALADINI, M.V., CAPELIN, D. and MARCHESE, C.F., 2009. Medicinal plants used by "Passo da Ilha" rural community in the city of Pato Branco, Southern Brazil. Anais da Academia Brasileira de Ciencias, vol. 81, no. 4, pp. 691-700. PMid:19893895. http://dx.doi.org/10.1590/S000137652009000400008

MARQUES, L.A.M., VALE, F.V.V.R., NOGUEIRA, V.A.S., MIALHE, F.L. and SILVA, L.C., 2011. Atenção farmacêutica e práticas integrativas e complementares no SUS: conhecimento e aceitação por parte da população são joanense. Physis (Rio de Janeiro, Brazil), vol. 21, no. 2, pp. 663-674. http://dx.doi. org/10.1590/S0103-73312011000200017.

MARTINS, C.C., ALVES, L.F.A. and MAMPRIM, A.P., 2016. Effect of plant extracts and a disinfectant on biological parameters and pathogenicity of the fungus Beauveria bassiana (Bals.) Vuill. (Ascomycota: Cordycipitaceae). Brazilian Journal of Biology = Revista Brasileira de Biologia, vol. 76, no. 2, pp. 420-427. PMid:27143049. http://dx.doi.org/10.1590/1519-6984.17914.

OLIVEIRA, E.R. and MENINI NETO, L., 2012. Levantamento etnobotânico de plantas medicinais utilizadas pelos moradores do povoado de Manejo, Lima Duarte - MG. Revista Brasileira de Plantas Medicinais., vol. 14, no. 2, pp. 311-320. http://dx.doi. org/10.1590/S1516-05722012000200010.

ORGANIZAÇÃO MUNDIAL DA SAUDE - OMS, 2012 [viewed 1 Oct 2012]. Traditional medicine: definitions [online]. Available from: http://www.who.int/medicines/areas/traditional/ definitions/en/

PEDROSO-JÚNIOR, N.N. and SATO, M., 2005. Ethnoecology and conservation in protected natural areas: incorporating local knowledge in superagui national park managemen. Brazilian Journal of Biology = Revista Brasileira de Biologia, vol. 65, no. 1, pp. 117-127. PMid:16025911. http://dx.doi.org/10.1590/ S1519-69842005000100016.
PILLA, M.A., AMOROZO, M.C.M. and FURLAN, A., 2006. Obtenção e uso das plantas medicinais no distrito de Martim Francisco, Município de Mogi-Mirim, SP, Brasil. Acta Botanica Brasílica, vol. 20, no. 4, pp. 789-802. http://dx.doi.org/10.1590/ S0102-33062006000400005.

RIBEIRO, A.Q., LEITE, J.P.V. and DANTAS-BARROS, A.M., 2005. Perfil de utilização de fitoterápicos em farmácias comunitárias de Belo Horizonte sob a influência da legislação nacional. Revista Brasileira de Farmacognosia, vol. 15, no. 1, pp. 65-70. http:// dx.doi.org/10.1590/S0102-695X2005000100014.

RODRIGUES, V.E.G. and CARVALHO, D.A., 2001. Levantamento etnobotânico de plantas medicinais do domínio cerrado na região do Alto Rio Grande - Minas Gerais. Ciência e Agrotecnologia, vol. 25 , no. 1, pp. 102-123.

SANTANA, G.M., DEUS, M.S., SOUSA, J.M., FERREIRA, P.M., FERNANDES, H.B. and PERON, A.P., 2016. Antimitotic and antimutagenic action of the Hymenaea stigonocarpa bark on dividing cells. Brazilian Journal of Biology = Revista Brasileira de Biologia, vol. 76, no. 2, pp. 520-525. PMid:27058600. http:// dx.doi.org/10.1590/1519-6984.23014.

SILVA, N. L. A.; MIRANDA, F. A. A.; CONCEIÇÃO, G. M. Triagem Fitoquímica de Plantas de Cerrado, da Área de Proteção Ambiental Municipal do Inhamum. Caxias, Maranhão. Scientia Plena, v. 6, p. 025402, 2010.

TOMAZZONI, M.I., 2004. Subsídios para a introdução do uso de fitoterápicos na rede básica de saúde do município de Cascavel - PR. Curitiba: Programa de Pós-graduação em Enfermagem, Setor de Ciências da Saúde, Universidade Federal do Paraná. Masters Dissertation.

TOMAZZONI, M.I., NEGRELLE, R.R.B. and CENTA, M.L., 2006. Fitoterapia popular: a busca instrumental enquanto prática terapêutica. Enfermagem, vol. 15, no. 1, pp. 115-121.

VENDRUSCOLO, G.S. and MENTZ, L.A., 2006. Levantamento etnobotânico das plantas utilizadas como medicinais por moradores do bairro Ponta Grossa, Porto Alegre, Rio Grande do Sul, Brasil. Iheringia: Série Botânica, vol. 61, no. 1-2, pp. 83-103.

VIEIRA, S.C.H., SÓLON, S., VIEIRA, M.C. and ZÁRATE, N.A.H., 2010. Levantamento de fitoterápicos manipulados em farmácias magistrais de Dourados-MS. Revista Brasileira de Farmacognosia, vol. 20, no. 1, pp. 28-34. http://dx.doi.org/10.1590/ S0102-695X2010000100007.

ZUCCHI, M. R.; OLIVEIRA JÚNIOR, V. F.; GUSSONI, M. A.; SILVA, M. B.; SILVA, F. C.; MARQUES, N. E. Levantamento etnobotânico de plantas medicinais na cidade de Ipameri - GO. Revista Brasileira de Plantas Medicinais, v. 15, n. 2, p. 273-279, 2013. http://dx.doi.org/10.1590/S1516-05722013000200016. 